\title{
Prerequisites for the development of digitalization in regional industry
}

\author{
Luyciena Piunko $^{1}$ and Elena Tolkacheva ${ }^{1}$ \\ ${ }^{1}$ EDP Sciences, Far-East Institute of management, branch of the Russian Presidential Academy of National \\ Economy and Public Administration (hereinafter RANEPA), Department of Mathematical Methods and \\ Information Technologies, Khabarovsk, 680000, Russia
}

\begin{abstract}
The study is a logical continuation of the study of the modern development of digital transformation in the economy of the Khabarovsk Territory in comparison with the average Russian development. At the same time, the regions of the Far East have their own specific difficulties in the development of the "Digital Economy". In this study, an attempt is made to compare the strategic goals of the development of the "Digital Economy", modern processes of digital transformation and such an important component of it as "Integration 4.0" - the fourth stage of evolution in industrial production associated with the "industrial Internet", digital production, intelligent components, including the collection of large amounts of data in many geographical areas, cyber-physical systems, remote monitoring and maintenance. "Industry 4.0 " helps to accelerate production processes, increase its efficiency, improve the quality of goods (products of production), reduce the cost of delivery, tracking production chains, etc. In the industry of Western countries, Industry 4.0 standards have already been developed and implemented in production management, the basis of which is horizontal and vertical integration of production. International standards are developed for industries that use computer algorithms to monitor and control physical things, such as equipment, robots and vehicles. All this ensures a high level of transparency and control over the activities of the organization. At the present stage, there are excellent opportunities for the development of Industry 4.0 in Russia, but there are also difficulties, overcoming which are significant directions of the digitalization processes of the modern economy.
\end{abstract}

\section{Keywords}

Industry 4.0, cyber-physical systems, digital transformation, robotics

\section{Introduction}

The transition from the third to the fourth industrial revolution is closely related to the development and integration of industrial Internet and Industry 4.0 standards into production. The third Industrial Revolution (Industry 3.0) was associated with the automation of industrial production through the development of electronics, information technology and software management, but did not include the widespread use of robots and wireless information networks. Cyber-physical systems are at the heart of the Fourth industrial revolution.

Referring to the national program "Digital Economy in Russia", it can be noted that the development of "Industry 4.0" is not explicitly stated in it, but the transfer of Russian enterprises to Industry 4.0 is implied in the federal project "Digital Technologies".

Today, Russia is significantly inferior to Germany, the USA, South Korea and China in the direction of the development of "Industry 4.0". The federal Digital Technologies project outlines the creation and

\footnotetext{
Proceedings of MIP Computing-V 2022: V International Scientific Workshop on Modeling, Information Processing and Computing, January 25, 2022, Krasnoyarsk, Russia

EMAIL: lusiena_03@mail.ru (Luyciena E. Piunko); e-v-tolkacheva@yandex.ru (Elena V. Tolkacheva) ORCID: 0000-0002-8938-130X (Luyciena E. Piunko); 0000-0003-1304-809X (Elena V. Tolkacheva)

(c) (i) (C) 2022 Copyright for this paper by its authors.

Use permitted under Creative Commons License Attribution 4.0 International (CC BY 4.0)

CEUR Workshop Proceedings (CEUR-WS.org)
} 
development of end-to-end digital technologies based on domestic developments: import substitution in quantum technologies, the development of high-tech products and services, 5G and other areas, which creates the necessary prerequisites for Russia's transition from Industry 3.0 to Industry 4.0. At the same time, Rosstat reported a decrease in the industrial production index by $2.9 \%$ in 2020 compared to $2019[12,13]$.

\section{Digital transformation of production in the region and prerequisites for the transition to "Industry 4.0"}

Modernization of Russian industry within the framework of "Industry 4.0" is being implemented today, for example, in the financial and energy sector very actively, but there are industries in which "Industry 4.0" is only being developed in regulatory documentation (food industry, machine tool construction, etc.). Note that in the west of Russia, with an active network of information and communication systems, the transition to "Industry 4.0" is already happening, albeit lagging behind developed countries, as well as China and India. In the Far East, with an extended territory poorly equipped with communication networks and information and communication equipment, the transition to "Industry 4.0" is being implemented in fragments and lagging behind the western regions of Russia.

\subsection{Scientific approaches to the study of the directions of development of "Industry 4.0"}

The issues of transition from Industry 3.0 to Industry 4.0 are considered by a number of scientists, for example, Sheve G., Huzig S., Gumerova G.I., Shaimieva E.Sh. [3]. Tarasov I.V. substantiates four principles of the concept of the fourth industrial revolution, one of which is the functional compatibility of man and machine, realized in the ability to contact directly via the Internet [4]. Volkova V.N., Leonova A.E., Loginova A.V., Karakchieva V.V. the issues of transformation of the integrated automated system of information support of production and enterprise management into a cyberphysical system are described [5]. Meshcheryakova E.N. lists the differences between cyber-physical systems and complex systems, while noting increased security, reliability and performance [6].

Thus, the scientific papers pay attention to the conceptual and methodological issues of modeling cyber-physical systems that contribute to the transition to "Industry 4.0", but the characteristics of the current level of development of cyber-physical systems and the readiness of industrial enterprises to implement them in the regional aspect are poorly presented. There is no analysis of the preparedness of personnel at enterprises for the introduction of cyber-physical systems and their use. Investigating the need for such a transition, scientists do not describe an approximate roadmap with the phased implementation of Industry 4.0 in Russian industry. At the same time, the fuel and energy industry and the financial sector of the Russian economy have successfully implemented automation and integration systems, cloud technology, Big Data, industrial data, corporate systems, artificial intelligence; i.e., the main concepts of the implementation of "Industry 4.0" $[5,16]$.

\subsection{Assessment of the development of "Industry 4.0" and digital transformation of production in the region}

In this study, we describe the prerequisites and prospects for the development of "Industry 4.0" technologies in the Khabarovsk Region. The implementation of the concept of "Industry 4.0." in the Khabarovsk Territory involves not just automation of existing production processes and processes of interaction between producer and consumer, but, first of all, the introduction of breakthrough business models and technologies based on digital platforms, digital ecosystems, in-depth analytics of large data arrays, the introduction of cyber-physical systems in factory processes. At the same time, currently not all districts of the Khabarovsk Region have access to the Internet, including 4G networks. From the northern remote areas of the Khabarovsk Territory, within the framework of infrastructure development, networks are being set up and subscribers are connected to them. The main interest in the 
deployment of the connection of districts and municipalities to the Internet is the Government of the Khabarovsk Region, funding is allocated for these purposes, including from the federal budget. At the same time, private business is the beneficiary of such development, but is not able to co-finance projects of digital transformation of production. The industrial Internet of Things is poorly developed.

The official website of the Khabarovsk Region Government provides information: "the share of organizations implementing technological innovations in the total number of surveyed organizations by 2015 to 18.2 percent, by 2024 to 23.00 percent" $[7,8,12]$.

\section{Table 1}

The proportion of organizations using digital technologies (as a percentage of the total number of surveyed organizations) $[8,9]$

\begin{tabular}{|c|c|c|c|c|c|c|}
\hline Indicators & 2016 & 2017 & 2018 & 2019 & 2020 & $\begin{array}{c}\text { Change in } \\
\text { the } \\
\text { indicator } \\
2020 \text { to } \\
2019 \text { in \% }\end{array}$ \\
\hline \multicolumn{7}{|l|}{$\begin{array}{c}\text { Organizations that } \\
\text { used: }\end{array}$} \\
\hline personal computers & 98.4 & 94.9 & 95 & 94.3 & 77 & $-18 \%$ \\
\hline local area networks & 73.3 & 67.8 & 66.9 & 65.6 & 52.4 & $-20 \%$ \\
\hline e-mail & 95.5 & 92.9 & 92.4 & 92.6 & - & - \\
\hline The Internet: & 97.2 & 93.3 & 93.1 & 93 & - & - \\
\hline $\begin{array}{l}\text { Fixed Internet (fixed } \\
\text { connections) }\end{array}$ & - & - & - & - & 74 & - \\
\hline mobile Internet & - & - & - & - & 36.5 & - \\
\hline Extranet & 19.1 & 19.3 & 21.6 & 22.9 & 18.8 & $-18 \%$ \\
\hline Intranet & 25.5 & 28.1 & 32.5 & 34.5 & 28.4 & $-18 \%$ \\
\hline $\begin{array}{c}\text { Organizations that } \\
\text { had a website } \\
\text { on the Internet }\end{array}$ & 58.9 & 53.6 & 54.6 & 56.2 & 42.1 & $-25 \%$ \\
\hline
\end{tabular}

Table 1 shows that for all indicators of the use of digital technologies by organizations, there was a decrease by about a fifth (about 20\%), despite the fact that the number of organizations by all forms of ownership in 2021 (compared to 2020) decreased by $7 \%$ [8, 9, 15].

The use of industrial robots and cybertechnical systems is also important in the concept of "Industry 4.0". The level of use of industrial robots in Russia is many times less than the world indicators. Based on official statistics and the results of a study by A. Shnipova, A. Pashkevich, the Business Profile Group, it can be noted: in the Russian Federation in 2018, 1007 industrial robots were installed (in 2017 - 713 robots), according to the National Association of Robotics Market Participants (NASR) deliveries increased by $43 \%$ compared to 2017 . At the same time, the robotization density index is quite low -5 robots per 10 thousand employees of enterprises in Russia, which is 20 times less than the average in the world, and only $5 \%$ of the installed robots were produced in the country [10].

In Russia, unlike developed and a number of developing countries, the production of industrial robots is absent on the scale necessary for the reindustrialization of the economy, the production of industrial robots of Russian companies is mainly made in single copies to order [10].

Sales figures in Russia for industrial robots are significantly lower than in many developed and developing countries. In 2019, 958 industrial robots were sold in Russia (98 more than in 2018). But of the purchased industrial robots, only $4.8 \%$ were of domestic production. The needs for the purchase of industrial robots, which were implemented at the end of 2018 for the automotive industry, amounted to $39 \%$, for mechanical engineering - 16\%, for the food industry (a multiple of less) $-4 \%$, in other industries $-37 \%$.

The number of sales of industrial robots in Russia is growing, information for the period $2011-2019$ is presented in Table 2 . 
Table 2

Dynamics of sales of industrial robots in Russia, units [10]

\begin{tabular}{cccccccccc}
\hline & 2011 & 2012 & 2013 & 2014 & 2015 & 2016 & 2017 & 2018 & 2019 \\
\hline Russia & 303 & 461 & 610 & 530 & 550 & 359 & 713 & 860 & 958 \\
\hline
\end{tabular}

The share of high-tech and knowledge-intensive industries in the gross product of the Khabarovsk Territory decreased in 2019, the information is shown in Table 3. At the same time, an increase in the share of knowledge-intensive industries in the regional gross product is an important component of sustainable socio-economic development of the region and an increase in the number of highly professional personnel of knowledge-intensive enterprises. Then, Table 3 shows that the Khabarovsk Region not only reduced the share of high-tech and knowledge-intensive industries in the gross product, but also (indirectly) reduced the number of highly professional personnel.

Table 3

The share of high-tech and knowledge-intensive industries in the gross product of the Khabarovsk Territory, as a percentage [13]

\begin{tabular}{lcccc}
\hline & 2016 & 2017 & 2018 & 2019 \\
\hline Khabarovsk Territory & 16.7 & 17.0 & 17.8 & 16.9 \\
\hline
\end{tabular}

A comprehensive modernization of production has been carried out at the aircraft manufacturing enterprises of the region. The complete transition to digital methods of design, technological preparation of production allows us to ensure high efficiency and competitiveness of products.

The main enterprises of the shipbuilding industry of the region are PJSC Amur Shipbuilding Plant (hereinafter referred to as PJSC ASP) and JSC Khabarovsk Shipbuilding Plant (hereinafter referred to as JSC KHSC), which are part of the structure of JSC Komsomolsk-on-Amur United Shipbuilding Corporation $[11,12,14]$.

\section{Analysis of regional policy on the development of "Industry 4.0" and digital transformation of production}

In general, it can be noted that in the Khabarovsk Region there are signs of a transition from discussing the concepts of "Industry 4.0" and related technologies to the first practical project programs. For example, agreements have been reached between the Government of the Khabarovsk Territory and PJSC VimpelCom on investing in the development of the digital infrastructure of the Khabarovsk Region, as well as on the formation of pilot zones for testing digital products. At the same time, in the Khabarovsk Territory there is a shortage of "niche" IT companies offering promising solutions in applied areas and clusters of "Industry 4.0" technologies: artificial intelligence, the Internet of Things, industrial robotics. Thus, in the All-Russian online intensive on artificial intelligence and data analysis "Archipelago 20.35", a product developed by companies from the Khabarovsk Region "Designer of artificial intelligence systems IONDV. Artificial Intelligence Framework" entered the top ten projects. Thus, potentially in the Khabarovsk Territory there are resources for the development of products that allow implementing projects to create artificial intelligence systems for practical application in industry $[7,11]$.

A characteristic feature by which it is possible to determine the stage of transition of the region to "Industry 4.0" is the increase in the number of mergers and acquisitions of companies. First of all, this is due to the speed of development of modern cyber-physical technologies. In this situation, regional companies do not have time to develop all the necessary competencies independently and unite to maintain competitiveness, or are absorbed by more technologically advanced federal companies. The merger of Khabarovsk companies is indirectly reflected in Table 1, in terms of reducing the use of equipment and Internet connection. Information about the reduction in the number of companies in the Khabarovsk Region is directly reflected in official statistics $[8,9,12,13]$. 
In addition, a sign of the region's transition to "Industry 4.0" is the growth of the sales market of supporting technologies, for example, industrial robots. It should be noted that despite the active formation of competencies for the robotization of various fields of activity among young people, in fact, the level of use of industrial robots in the Khabarovsk Territory is low. [12,14].

At the same time, there is no data on the use or purchase of industrial robots at the leading enterprises of the Khabarovsk Region [14, 15].

Serious barriers in the development of "Industry 4.0 " in the Khabarovsk Region are the following phenomena:

1. Weak bandwidth and instability of the Internet on the territory of the Khabarovsk Region, especially in remote areas (or their complete absence in certain territories of the region).

2. Dependence of Russian technologies on hardware manufactured abroad.

3. Lack of investment funds for the implementation of complex digitalization projects in the Khabarovsk Territory.

4. A long transition from pilot projects to the mass introduction of innovations in the production of serial products.

Thus, the previously described signs of the development of "Industry 4.0" in the Khabarovsk Region allow us to draw conclusions about the potential for the introduction of cyber-physical technologies into the activities of industrial enterprises and government agencies. In the process of operation of cyberphysical systems, a sufficiently large and heterogeneous set of data on the manufacturer's work processes, sensor data, estimates of loss factors, etc. is formed. Processing of this information by the manufacturer involves the introduction of data mining tools. In this regard, the main problem can be identified as the need to bring fundamental science and applied developments that are being conducted in the Khabarovsk Territory to one strategic goal to ensure the socio-economic development of the region in the short and long term.

The evolution of technologies in industry, implying that traditional production processes are integrated with information and communication technologies (ICT / IoT) and information systems of the manufacturer and represents "Industry 4.0".

Currently in China, Germany, South Korea, etc. with the development of microelectronics, programming technologies, information and communication technologies, the use and production of collaborative robotics and control technologies for large groups of unmanned vehicles moving on land, air and water are actively developing. In Russia, an analogue of collaborative robotics has been used for a relatively long time in nuclear reactors: control and measuring equipment. At the same time, the use of collaborative robotics is now being integrated into production cycles at Russian production facilities and this area is being given close attention by developers $[16,17]$.

The implementation of the federal Information Infrastructure project in the Khabarovsk Region in terms of creating a competitive, sustainable and secure infrastructure for high-speed data transmission, accessible to all citizens, businesses and authorities, will ensure the connection to the Internet of key socially significant infrastructure facilities, as well as allow the population to use high-quality modern digital services. The development and integration of "Information Infrastructure" and "Digital Technologies" will create an impetus for the widespread introduction of the industrial Internet of Things and cybertechnical systems.

At the moment, a number of measures have been implemented on the territory of the Khabarovsk Region to provide remote territories with a stable Internet connection and to connect state (municipal) educational organizations, central election commissions to a Unified Data Transmission Network (ESPD) in order to ensure not only secure access to state and municipal information systems, but also to create a secure Internet space.

At the same time, the roadmap for the transition to "Industry 4.0" in the Khabarovsk Territory should be developed, in our opinion, taking into account the following tasks:

1) modernization of the Internet, and their universal grip on the territory of the Khabarovsk Region, including hard-to-reach areas;

2) support of Russian companies engaged in the production of robotics, priority purchases of collaborative robots from them (with a preliminary assessment of the quality and their payback);

3) integration of production chains by means of information and communication technologies with the connection of unified data transmission networks by type of production. 
The proposed list of measures is not, in our opinion, exhaustive, it can be supplemented with proposals for optimizing fixed assets with an assessment of the possible risks of such optimization and modernization; an assessment of human resources; costs for training and retraining specialists who can work with industrial robots. But we note that the development of the industrial Internet is an important connecting element for the modernization of production as a whole.

At the same time, the key elements of the conceptual model of socio-cyberphysical systems are people who participate in feedback with technical devices. This implies the active use of a feedback system represented by network/distributed and intelligent systems, the operation of which is possible in conditions of access to the Internet. Thus, it is necessary to further implement the regional policy to create conditions for the development of Industry 4.0. on the territory of the Khabarovsk Region, further work will be carried out on the development of infrastructure for connecting both industrial organizations and the population to the Internet.

\section{Conclusions}

"Niche" IT companies continue to appear in Russia, offering promising solutions in applied areas and clusters of "Industry 4.0" technologies: artificial intelligence, the Internet of Things, industrial robotics.

Such areas as "Industrial Internet" and "Industry 4.0" are not directly stated in the federal project "Digital Technologies", but are designated by the creation and development of end-to-end digital technologies based on domestic developments, the development of high-tech products and services, import substitution in quantum technologies, $5 \mathrm{G}$ and other areas. These developments are partially implemented by state corporations (Roscosmos, Rostechnologies, Rosatom, etc.).

It is necessary to develop analogues of Western concepts of "Smart Production" in the Khabarovsk Territory, but for this you need:

- modernization of the Internet, and their universal grip on the territory of the Khabarovsk Region, including hard-to-reach areas;

- support of Russian companies engaged in the production of robotics, priority purchases of collaborative robots from them (with a preliminary assessment of the quality and their payback);

- integration of production chains through information and communication technologies with the connection of unified data transmission networks by type of production.

For the Khabarovsk Territory, the introduction of the concept of "Smart Production" is currently being considered for large enterprises in the region, its implementation is necessary, taking into account the peculiarities of the Russian socio-economic space.

In Russia, official documents regulating the development programs of "Industry 4.0" are only at the development stage. At the same time, the measures being developed as part of the implementation of the federal Information Infrastructure project are important for the development of Industry 4.0 in Russia, including in the Khabarovsk Region.

The share of high-tech and knowledge-intensive industries in the gross regional product in the Khabarovsk Territory is insufficiently represented and has a downward trend. It is necessary to develop public administration measures to correct this negative trend. Because the prerequisites for the development of "Industry 4.0 " in the Khabarovsk Region are currently.

\section{Acknowledgements}

This work was supported by Far-East Institute of management, branch of the Russian Presidential Academy of National Economy and Public Administration (hereinafter RANEPA), Department of mathematical methods and information technologies, Khabarovsk 680000, Russia. 


\section{References}

[1] D. Kim, A. Hwong, D. Stafford, A. Hughes, J. O'Malley, J. Fowler, Social network targeting to maximise population behaviour change: a cluster randomised controlled trial, The Lanclet 386(9989) (2015) 145-153.

[2] E. Piccinini, R.W. Gregory, L. Kolbe, Changes in the Producer-Consumer Relationship - Towards Digital Transformation (2015). URL: //https://www.researchgate.net/publication/277325460_Ch anges_in_the_Producer-Consumer_Relationship_-_Towards_Digital_Transformation.

[3] G. Sheve, S. Huzig, G.I. Gumerova, E.S. Shaimieva, From Industry 3.0 to Industry 4.0: basic concepts, measurements and components of Industry 4.0, Investments in Russia. Moscow 9(296) (2019) 32-40.

[4] Ivan Vladimirovich Tarasov, Industry 4.0: concept, concepts, development trends, Business strategies 6(50) (2018) 57-63.

[5] V. N. Volkova, A. E. Leonova, A. V. Loginova, V. V. Karakchieva, Development of automation of information support for enterprise management systems based on the concept of a cyberphysical system, System analysis in design and management of the XXIII International Scientific and Practical Conference. Collection of scientific papers. St. Petersburg. (2019) 274-288.

[6] E. N. Meshcheryakova, From complex technical systems to cyberphysical systems. Modern information technologies (Penza). 30 (2019) 51-54.

[7] Official website of the Khabarovsk Region Government: section "Innovative development and modernization of the Khabarovsk Region economy", 2021. URL: https://www.khabkrai.ru/khabarovsk-krai/Proekty/Gosudarstvennye-celevye-programmy/700.

[8] Official website of the Federal State Statistics Service: section "The proportion of organizations that used digital technologies (as a percentage of the total number of surveyed organizations)". URL: https://habstat.gks.ru/storage/mediabank/Main\%20indicators\%20 usage\%20information (2).htm.

[9] Official website of the Federal State Statistics Service: section "Distribution of enterprises (organizations) by ownership forms". URL: https://habstat.gks.ru/storage/mediabank/Pacпpe деление\%20enterprises\%20по\%20формам\%20собственности\%20на\%2001.07.2021.htm.

[10] Alexandra Shnipova, Alexandra Pashkevich: Business Profile Group. Analytical research. The use of industrial robots: an overview of the robotics market in Russia and the world (2020). URL: https://delprof.ru/upload/iblock/987/DelProf_Analitika_Rynok-robototekhniki.pdf.

[11] Official website of the Khabarovsk Region Government: Industry section. URL: https://www.khabkrai.ru/khabarovsk-krai/Razvitie-kraya/184.

[12] Official website of the Federal State Statistics Service: section "On industrial production in 2021". URL: https://gks.ru/bgd/regl/b21_01/Main.htm.

[13] Official website of the Federal State Statistics Service for the Khabarovsk Territory: section "On industrial production in 2021". URL: https://habstat.gks.ru/vrp_hbr.

[14] Official website of the Ministry of Industry and Trade of Russia (2021). URL: https://minpromtorg.gov.ru/press centre/news/\#!minpromtorg_i_rosstandart_obnovili_perspektiv nyy_plan_standartizacii_tehnologiy_industrii_40.

[15] Official website of the Federal State Statistics Service: section "Digital Economy of the Russian Federation". (2021). URL: http://www.gks.ru/free_doc/new_site/figure/anketa1-4.html.

[16] Innovative development of economic systems in the context of digitalization. Monograph, Under the scientific editorship of Doctor of Economics Veselovsky M.Ya. and Candidate of Economic Sciences Khoroshavina N.S. World of Science, Moscow (2021). Online edition. URL: https://izdmn.com/PDF/07MNNPM21.pdf - Blank from the screen.

[17] I. Sidorina, The Russian machine tool industry is preparing the Renaissance. Newspaper "Expert". 3 (2021). Online edition. URL: https://expert.ru/2021/09/14/rossiyskomu-stankostroyeniyugotovyat-epokhu-vozrozhdeniya/ 